\title{
Border as Post Space in Reyna Grande's The Distance Between Us
}

\author{
${ }^{1}$ E. Ngestirosa Endang Woro Kasih, ${ }^{2}$ Ida Rochani Adi, ${ }^{3}$ Nur Saktiningrum \\ Universitas Gadjah Mada, Lecturer of Teknokrat Universitas Indonesia ${ }^{1}$ \\ Universitas Gadjah Mada ${ }^{2,3}$
}

\{ngestirosa@teknokrat.ac.id ${ }^{1}$, ida.rochaniadi@mail.ugm.ac.id ${ }^{2}$, nursaktiningrum@ugm.ac.id ${ }^{3}$ \}

\begin{abstract}
Reyna Grande's The Distance Between Us delivers another definition of a term border illustrated by the Mexican immigrants or later called Chicano in the United States. To construct the definition, Sara Upstone's postcolonial theory is applied for the analysis of the novel. Literally, 'border' is considered a gate as a place to provide an entrance or an opening used for passage. Thus, this novel depicts the mixture of cultures as a result of struggle committed by the main character of the novel through the passage. However, due to the emergence of chaos as the result of the mixing process, the border is not solely interpreted as a geographical territory but considered a postspace as the mixing involves a breach to an area or space.
\end{abstract}

Keywords: border, Chicano, chaos, mexican, postspace, postcolonial

\section{INTRODUCTION}

Border discourse in the context of the border between The United States and Mexico plays the most important part of the history of the United States. Hence, the texts on the border become an inevitable part. This also correlates to the issue of the border wall proposed by Trump in his campaign [1], [2]. Border texts later came as part of Chicano literature or United States literature. It dates back in 1848 when Mexico and the United States signed the Treaty of Hidalgo Guadalupe, resulting in that most of Mexico land was seized into the territory of the U.S. [3], [4]. Border texts that emerged as the subsequent effect serves as the commencement for the entry of various Chicano or Mexican American literature and eventually shaped the identity of Mexican American literature. This marks the development of Chicano literature or Mexican American [5]-[7] literature as part of American literature.

The development of Chicano literature was then followed by the publication of Chicano literature which was always also associated with border issues. The emergence and rise of literature began with the publication of the novel Pocho by Jose Villarel, which delineates the life of Mexicans in the United States [8], [9]. This literary work involves a border issue, which is about people crossing the border from Mexico to the United States and about Chicano people living in the United States. This proves that there is a relationship between white people and Mexican society which describes the intersection between the two of them. The contact then raises colonial issues [10], which mostly reveal the dominance of white groups in the Chicano minority group. This indicates that Chicano literature as part of American literary works gives rise to colonial issues in it, namely Chicano as a colonized society and white society as a colonial society.

Postcolonial discourse in American literary works is interpreted not about power relations between countries in border areas but also relationships within it [11]-[13]. Colonial discourse 
in Chicano or Mexican-American societies has always been associated with the borders of the United States and Mexico as gray areas or liminal areas [14], [15]. The border area is also considered gray zones [16] and in between spaces [17]. The border is always associated with Chicano which is a picture of colonial relations between the United States and Mexico[18]. The border finally also reveals the identity of the Chicano people conceptualized as "juggling cultures" who are considered to have hybridity identities [19] or plural personalities [20, p. 46]. Hybridity identity occurs because there is a colonial experience in Mexican society in the United States, for which most of the research [21], [22] finally illustrated in most Chicano literature shows the colonial experience of Mexican society in the United States. Chavez [23] says that the Mexican American community is an alien in their own country. Anzaldua in Saldivar [24] reveals that there is internal colonialism in the Chicano community: "Native borderlands were seized and privatized by Anglos, their Texas Rangers, and their lawyers". This proves that colonial discourse is closely related to the life of the Chicano people in America.

One of the Chicano literary works which gives rise to colonial issues as a result of border crossers namely the Reyna Grande novel entitled The Distance Between Us. This novel tells the story of the life of Reyna and her siblings living in Mexico and the United States. They then have to cross the border and later move to the United States. They experience a new life by living with their father and stepmother. The cultural differences between Mexico and the United States result in Reyna and her siblings having to experience various conflicts with their father and stepmother in one house. Conflict also arises with outside activities involving anger and support and his father. This has an influence on the lives of Reyna and her later siblings in the United States.

This research focuses on the colonial experience experienced by the author, Reyna Grande herself. Although the author's background and novel stories are deeply indicating about the postcolonial discourse, there has been no discussion in the Trump era border discourse by using Sara Upstone's theory of the Mexican American community. This is interesting when it is associated with Trump's desire to build a border wall between Mexico and the United States. Research then becomes an alternative discussion of postcolonial discourse that occurred at the present time.

\section{METHODOLOGY}

This study applies Sara Upstone's postcolonial theory [25] in his book Spatial Politics In The Postcolonial Novel which offers a critical method of reading postcolonial novels. Upstone refers to nation, place, body and space that emphasize the existence of political practices that occur not only in the state space, but also in other spaces. This theory is more referring to the way of reading literature [26, p. 33] which means that literary works can be read through the colonial perspective in them. Upstone also explaines that the place signifies colonial control, while space refers to things that are broader and more flexible, forms that the colonial wants to obscure. Space is a room in an abstract sense where hegemonic concepts can be embedded because of their flexible nature. Space becomes a colonial territory to maintain the stability of colonialism so that there were boundaries that were revealed as natural boundaries to construct society. By reviving colonial territory in the space of colonized people, boundaries are increasingly seen and colonial power seemed absolute, fixed [25, p. 4]. Postcolonial theory reads the politics of the colonial space and describes what has been obscured. The postcolonial texts question various other possibilities for the order instilled by colonialism. Reading the space in a postcolonial context provides possibilities for identity negotiation and possible resistance. Upstone [25] offers a reading of these postcolonial experiences which are constructed within several spaces, including state space, travel space, city space, house space, and body space. 
Therefore, the study mainly focuses on exploring home space as a place to realize colonial relations.

\section{FINDING AND DISCUSSION}

\section{a. Border as Colonial Space}

The Distance Between Us reveals the borders built by the state, America and Mexico, as postcolonial boundaries. In this case, the border is always in conflict with the relations of the world state behind the borders of the non-developed and more developed countries. The border allows border crossers to move across the border to get better conditions. In the debate with the border between the United States and Mexico, the border has become a colonial monument. Mexico has always been regarded as a colonized country and the United States as a colonial state. This relationship is considered as an alternative space that allows the postcolonial movement. Colonial relations exist because of experiences in the Chicano community group.The border areas of the United States and Mexico often known as La frontera, El Otro Lado and North by Mexican people are considered open wounds [27] for most border crossers. Borderers must deal with brokers who are often called coyote (a smuggler who transport illegal Mexican immigrants to the U.S.) and other things to cross the border because they do not have official documents. For this reason, border crossers are often referred to as undocumented immigrants, wetback and illegal aliens [28]. Border crossers are also called as cases, dirty, immoral, and disease-borne [28]. The title given by white people indicates that there was colonial discourse in the Chicano group.

The border area eventually became a colonial region as a place where the rulers and colonies met, namely white Americans and Mexicans as revealed by. The border area is a space of conflict as said by Upstone. This novel is about the life of Reyna Grande [29] in the United States. In the novel discussed now, Reyna Grande as the main character must feel himself crossing the border illegally which is actually dangerous for himself and his brothers. However, in order to reach a dream of a better life in America, all obstacles must be faced. When her parents make dangerous and illegal trips across the Mexican border to pursue the American dream, Reyna and her siblings are forced to live with their harsh grandmothers, when they wait for their parents to build the foundation of a new life.When crossing the border, the main character experiences unpleasant experiences to cross the border by settling in and running to avoid border officers or la migra. Even though coyote has been assisted as a link at the border, the main character still has to do it carefully. The main character also shares his experience of growing up in the small town of Mexico where his parents want to build a house. Because the economy is in bad condition, her father goes to the US to work, and her mother immediately joins with her. She and her brothers are left in the care of their father and step mother, who do not really care about them.

Mexico and the United States are a nation. As revealed by Reyna, the need to cross the border is for better life Please God, let arrive safely to El Otro Lado. I want to live in that perfect place. I want to have a father. I want to have a family [29, p. 157]. The border which is an empty area with various kinds of threats that might come from officers la migra is considered a perfect place. 


\section{b. Home as Postspace}

Borders involving Mexico and the United States in smaller colonial relations occur within the house. This place can play a political role in carrying out colonial values as one of the constructions that play a role in carrying out political functions in upholding colonial values, and this role is displayed paradoxically in the idealization and apolitization of the house [25, p. 115]. Colonial relations in the home propagate the colonial state discourse with various strategies. The strategy used to inculcate this discourse in the thinking of its colonies is to make the house a fixed, rooted, stable location, the antithesis of travel. Liquidity from the house is obscured while the ideal harmony of the house is raised by propagating the view that the home is the location of promoting values and behavior that are considered crucial to forming and maintaining national identity, and is the necessary protection from social change and unexpected economic conditions [25, p. 117].

In the house there are family members consisting of father, mother and child. Reyna lives with her biological father, Mila, her stepmother and Mago and Carlos's siblings. Her father has lived in the United States for a long time and lives with his stepmother. His father was a Mesiko and his stepmother was also a Mexican but had received US citizenship. Being able to adjust to American culture, Reyna's father is used to live with Mila and forget the culture and habits of Mexico. Mila does not have the thoughts that is in accordance with her place of origin, Mexico. Reyna's father and stepmother have the same idea to set rules that are appropriate for the situation in the United States. This allows the husband and wife to become colonial rulers in the house and then establish regulations. Whereas Reyna, Mago and Carlos must receive the colonial practice because they are immigrants.

Relationship among Reyna, her father and her stepmother becomes colonial relations in the small form in the house. The house for Reyna is a foreign place that must be inhabited. The apartment-shaped house with only one bedroom is a common house left by small families in the United States. usually only consists of one living room, one bed and kitchen and a place to live in the United States for the main character with two other siblings. The house for Reyna and the brothers becomes a foreign place so that she becomes a person who must obey all the rules created in the house along with the existing bulkhead partition. Colonial concept in the house can be seen on a clean and order floor. The apartment occupied by Reyna and her siblings and their father and stepmother is a clean room like other apartments. This situation shows a different situation with Reyna's house in Mexico that is not clean and there are many scorpions everywhere.

According to Upstone in terms of postcolonial criticism, home can be linked to political battles since a domestic space in homes can result in the occurrence of resistance efforts with radical political dimensions [25, p. 16]. The house creates colonial relations. Reyna and her brothers from Mexico must obey all the rules set by their father and stepmother. Grande's house becomes boundaries that should not be violated. With regard to the hierarchy and divisions applied by colonial powers in the house, it appears that the house has fixed boundaries in forms of rules. They are set up such as cleanliness and use of the room and the tools inside. After leaving his father in Mexico for six years and then reliving together with his father, this brings Grande to an adjustment that must be done again. Reyna must adjust to the life of her stepmother who has a different attitude to her biological mother. There are cultural differences that are felt by the main characters as teenagers who must understand new cultures so that conflicts arise resulting in the anger of the stepmother. Colonial relations here are created by his stepmother by making rules that the stepchildren must not enter her bedroom. In this case, the boundary cannot be fluid so that the bedroom not only a place as a territory but also as a space that cannot be violated. 
When we first arrived in the U.S., Mago and I went into Mila and Papi's bedroom to look at her pretty clothes in the closet and to smell her perfumes. I knew Mila had noticed we did because a few days later Papi installed a new doorknob that locked, and from that moment on they would lock their door every time they left the house $[29$, p. 186]

Reyna, Mago and Carlos also unwittingly violated the rules applied by the authorities from her father and stepmother. They begin to get used to electronic devices that they do not normally find in Mexico. Without realizing it, they like things that are related to the mentality of the ruler. The three siblings are then able to use television and begin to like television when their father and stepmother left to work. At one point they use the telephone to call Santa Clause on television to request the desired gift. Limited knowledge about TV shows made the three brothers use the telephone wrongly for an unknown purpose. They didn't get the prizes they asked for using the telephone because it was only a television program. The existence of these violations of boundaries eventually led to chaos. The three of them did not know that using a telephone would incur costs. When the telephone bill swells, then it arouses anger from his father and stepmother.

\footnotetext{
"What's this?" Papi said, holding a bill in his hand. "Who in the world did you call? Why is the bill so high?" Mago, Carlos, and I looked at each other. We never used the phone. We didn't know anyone here, so who would we call?

We walked up to the phone and saw the lock on it, so now we couldn't turn the little wheel to dial unless we put in a key. [29, p. 196]
}

There is disorder in the form of space. On the one hand, the love of the three brothers will be television and Santa Clause causes the boundary to be space. They like television programs and without realizing it, this causes postspace. The three brothers began to use the telephone to find other pleasures that were in the ruler's culture, namely the promised gift will be given by Santa Claus. Colonial activities also occur when the main character experiences conflict over the boundaries that are violated, namely telephone use at home. The main character as a Mexican child does not understand that using a telephone will incur costs. This raises the anger of his father and stepmother when he learns that the boundary has been violated so that he then decides to lock it. But there is some momentum when the border becomes space.

Family relation makes the boundary fluid. Relationship between biological father and biological child allows the boundaries to be violated. Reyna's father still provides a place for his kids to sleep in a certain room. Even though it is not a proper place, it gives them space which different one another. Reyna's father uses a living room as bedroom for his three kids and a TV viewing room for his stepmother to be a sleeping area for them at night. Even though this caused inconvenience to his stepmother, it continued until they found a bigger apartment. With this, post-colonial homes will reveal that in the hierarchy and boundaries of colonial houses there are irregularities and chaos [25, p. 124]. The main characters in this novel must break the boundaries that exist because they cannot sleep in one room with their mother and father, thus creating irregularities in the functions of the existing spaces.

"We left the kitchen and went into the living room, where my stepmother was watching TV. Seeing us come in, Mila got up and headed to the bedroom, the only one in the apartment. Mago, Carlos, and I had been sleeping in the living room since we arrived from Mexico [29, p. 166] 
Space occurs when the function of the family room puts into conflicts. Mila, her stepmother, does not fully support the idea of using the living room as the bedroom. Postcolonial discourse also wants to reveal that chaos in the home occurs because not all residents of the house support the colonial ideal [25, p. 128]. The tension that occurs in the house is to be revealed, and liquidity will be raised. Thus, it is clear that postcolonial homes are no longer to serve colonial interests, but to serve other purposes which ultimately damage the power relations that have been built by the colonial concept [25, p. 131]. Mila, her stepmother was forced to obey her step daughter to sleep in the guest room. In this case Mila does not succeed in implementing the regulations that had been set. The house then forms space to become fluid because there is a boundary that is violated.

The boundary also becomes liquid and not liquid for other momentum which is in accordance with the wishes of the ruler, Mila. His stepmother provides food that is characteristic of the United States, namely spaghetti. Even though Mila is from Mexico, she knows more about typical American food. The spaghetti dish is a noodle-shaped meal and Mago and Carlos like the food. Conversely for Reyna the food was a disgusting thing because it reminded her of the shape of a worm. Reyna's disobedience to the food her stepmother had provided with difficulty caused her father to become angry.

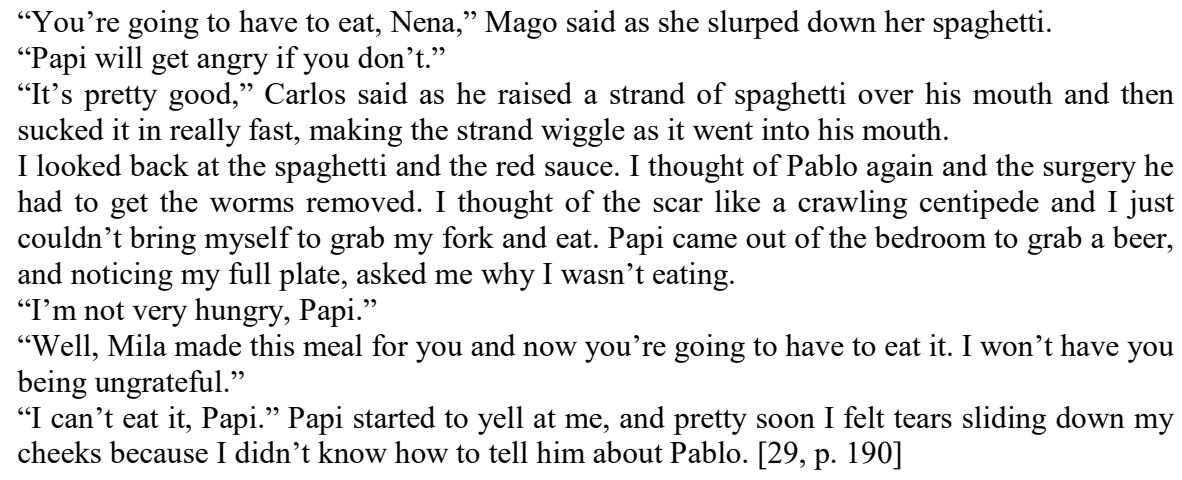

In this momentum Reyna's father had become a mental ruler in accordance with the United States. Reyna's father eventually became the ruler's mentality that created rigid regulations by forcing his son to eat spaghetti even though his son didn't like it. He did not understand that his child did not like the food. For him sphagetti food is a good food. Reyna's father did not realize that he had become more American because he liked the food as well as his other children, Mago and Carlos. They both finally began to feel pleasant things with the culture of the ruler.

On the other hand, Reyna has not been able to accept it so the boundary became chaotic.In other momentum, the boundary in the house is also a space when there are certain celebrations that are in accordance with the wishes and culture of the ruler of the house. Thankgiving is a special celebration for American society. Reyna and Mila's father got used to the event. The culture was then also socialized to Reyna and her younger siblings. Mila's stepmother began to ignore the boundaries they had. He encouraged Reyna, Mago and Carlos to take part in hallowen activities, namely 'trick and threat'.

"I'm making you a Halloween costume," she said. A costume? Out of a sheet? She walked him over to the closet door so Carlos could see it for himself. He turned to look at us. Mago and I giggled. My brother was now a ghost. It was amazing. From that year on, Mila always brought us white sheets for Halloween, and she never bought me a costume again. If I had 
known she would do that, I wouldn't have praised Carlos's ghost costume so much. "Let me see what I can come up with for you, Mago," Mila said. We looked out the window and saw that kids were starting to come out of their houses with their costumes on. [29, p. 180]

The desire to apply the culture of the ruler causes Mila to break the boundaries. She gave and made Halloween costumes for her children. The rigid treatment given to her children becomes fluid when she likes her relationship to make a costume for the trick and threat event. The relationship between the two becomes melted so that the boundary becomes liquid. Hallowen creates space into postspace so Mila happily makes costumes for Carlos and Mago but not for Reyna.

Mila violates space when she applies her position to become a mother. Her motherhood that cannot be expressed on the biological child is then expressed to her stepdaughter. When Reyna suffered a toothache she gave up using insurance on behalf of her biological child for Reyna's sake. Mila also behaves like her biological mother when delivering Reyna to the dentist. Reyna feels comfortable to be have 'Mama' for a while. On the other hand, she turns sad by having knowledge that Mila does not want to be called "Mama"

\footnotetext{
"Your daughter was very good," the receptionist said as Mila and I went out the door. Mila held me by the shoulders because I was feeling a bit dizzy and my mouth was numb and my lips felt three times their usual size. My lips throbbed as if they'd been stung by a scorpion. "Thank you," Mila said. I waved goodbye to the receptionist and gave her a groggy smile. On the way home, Mila was very quiet. I wondered if she was thinking about her daughter. "Are you in pain yet?" she asked as we pulled into the driveway. "No, Mamá Mila," I said. Maybe it was the anesthesia that had made me say that. Mila took a deep breath and then looked at me. "Just call me Mila. I'm not your mom so you can't call me Mamá. Just Mila, okay?" She said it gently, and yet I felt as if she had yelled at me. The harshness in her voice was very subtle, but I could hear it clearly. With tears in my eyes, I said, "I'm sorry, Mila. I won't do it again." Then I got out of the car and went into the house, where I saw that my brother and sister were back from school $[29$, p. 185]
}

Mila forgets herself as a ruler and positions herself as a mother. At certain times, space then becomes post space when Mila becomes a mother for accompanying Reyna in the hospital. According to Upstone [25, p. 15], post-space is a concept that is outside the colonial boundaries or brick-boundaries of tradition, even beyond or before the boundaries arise; it can also be said to be a hybrid, liquid and moving space, so that it has no more boundaries. On the other hand post space then becomes space again followed by the order. Mila feels that the call "Mama" was not for her so she becomes angry for the term "Mama" on her. The boundary becomes fluid because the desire to be a mother, beside one side of the border becomes static because there are rules that are violated so that it causes chaos.

\section{CONCLUSION}

The novel shows the border as colonial space. Movement past the border is a movement to colonial space. The movement occurred in the postcolonial context. In this context, homes are present as postspace. The author realizes that home is not always a construction in the formation of postspace. Postspace occurs only under certain conditions. On the one hand, chaos continues to occur so that postspace can change into space. There are still borders that are violated but with an understanding of both parties, namely the party giving the order and receiving the order. Chaos becomes less due to the understanding of the available space. But this cannot create 
postspace because the space created is still a compulsion for the given order. Thus, it can be said that this novel is constantly opposed to the construction that was formed. The boundary construction can be resisted by making it post-space, and the existing post-space is also canceled by forming a bounded space. If it is related to the context of Mexican society in the United States, this group will easily adjust to the situation in the United States. The authorities will also not carry out the colonial concept when the colonized Mexican community in the United States begins to abandon the Mexican tradition. But in this novel, the strategy offered does not consider postspace a final solution. Compliance with colonial parties is not always necessary.

\section{Acknowledgment}

I would like to send my great gratitude to the Directorate of Research in Universitas Gadjah Mada for providing the support for postgraduate student in UGM. I would also like to give great thanks to Universitas Teknokrat Indonesia for great support and financial in my dissertation process.

\section{References}

[1] G. R. Sanchez and B. Gomez-Aguinaga, "Latino Rejection of the Trump Campaign Latino Electorate as Never Before," Aztlán A J. Chicano Stud., pp. 165-181, 2016.

[2] C. Schubert, "Constructing Mexican Stereotypes: Telecinematic Discourse and Donald Trump's Campaign Rhetoric," Crit. Approaches to Discourse Anal. Across Discip., vol. 8, no. 2, pp. 37-57, 2017.

[3] R. Acuna, Occupied America. San Francisco: Canfield Press, 2004.

[4] A. O. Eysturoy and J. A. Gurpegui, "Chicano Literature: Introduction and Bibliography," Am. Stud. Int., vol. 28, no. 1, pp. 48-82, 1990.

[5] J. A. Cutler, “On Recent Chicano Literature," West. Am. Lit., vol. 44, no. 2, pp. 158-167, 2009.

[6] F. A. Lomeli, "Survey of Chicano Literature," Chicano Stud., vol. 15, no. 1, pp. 135-148, 1990.

[7] M. Kaup, "The Architecture of Ethnicity in Chicano Literature," Am. Lit., vol. 69, no. 2, pp. 361-397, 1997.

[8] G. Haslam, “; Por La Causa! Mexican-American Literature Author,” Coll. English, vol. 31, no. 7, pp. 695-700, 1970.

[9] A. Marquez, "The American Dream in the Chicano Novel," Rocky Mt. Rev. Lang. Lit., vol. 37, no. 1, pp. 4-19, 1983.

[10] A. S. Ribeiro, "Translation as a Metaphor for our Times: Postcolonialism, Borders and Identities," Portuguese, vol. 20, no. 2004, pp. 186-194, 2004.

[11] A. Singh and P. Schmidt, "On the Border between US Studies and Postcolonial Theory," in Postcolonial Theory and the United States: Race, Ethnicity, and Literature, A. Singh and P. Schmidt, Eds. Mississippi: University of Mississippi Press, 2000.

[12] M. J. Schueller, "Postcolonial American studies," Am. lit. Hist., vol. 16, no. 1, pp. 162 175, 2004.

[13] R. Saldívar, Chicano Narrative: The Dialectics of Difference. Madison: The University of Wisconsin Press, 1990.

[14] J. D. Saldivar, "Chicano Border Narratives as Cultural Critique," in Criticism in the Borderlands: Studies in Chicano Literature, Culture and Ideology, H. Calderon and J. D. Saldivar, Eds. London: Duke University Press, 1991, pp. 167-187.

[15] J. D. Saldivar, Trans-Americanity: Subaltern Modernities, Global Coloniality, and the 
Cultures of Greater Mexico. Durham, London: Duke University Press, 2012.

[16] T. J. Kynčlová, "Elastic, Yet Unyielding: The U.S.-Mexico Border and Anzaldúa's Oppositional Rearticulations of the Frontier," Eur. J. Am. Stud., vol. 9, no. 3, pp. 1-17, 2014.

[17] H. K. Babha, The Location of Culture. New York: Routledge, 1994.

[18] R. Pérez-Torres, "Chicano Ethnicity, Cultural Hybridity, and the Mestizo Voice," Am. Lit., vol. 70, no. 1, pp. 153-176, 1998.

[19] B. T. Kurki, "Borders from the Cultural Point of View: An Introduction to Writing at Borders," Cult. Unbound, vol. 6, pp. 1055-1070, 2014.

[20] J. Vasquez, "Blurred borders for some but not 'others': Racialization, 'flexible ethnicity,' gender, and third-generation Mexican American identity," Sociol. Perspect., vol. 53, no. 1, pp. 45-72, 2010.

[21] P. Hamalainen and S. Truett, “On Borderlands,” J. Am. Hist., vol. 98, no. 2, pp. 338-361, 2011.

[22] E. Jameson and J. Mouat, "Telling Differences: The Forty-Ninth Parallel and Historiographies of the West and Nation," Pac. Hist. Rev., vol. 75, no. 2, pp. 183-230, 2006.

[23] J. R. Chávez, "Aliens in Their Native Lands: The Persistence of Internal Colonial Theory," J. World Hist., vol. 22, no. 4, pp. 785-809, 2011.

[24] J. D. Saldivar, "The Dialectics of Our America: Genealogy, Cultural Critique and Literary History." Duke University Press, Durham, 1990.

[25] S. Upstone, Spatial Politics in the Postcolonial Novel. Burlington: Ashgate Publishing Company, 2009.

[26] J. McLeod, Beginning Postcolonialism. Manchester: Manchester University Press, 2000.

[27] G. Anzaldua, Borderlands. San Francisco: Aunt Lute Book Company, 1987.

[28] J. D. Saldivar, Border Matters: Remapping American Cultural Studies. Berkeley: University of California Press, 1997.

[29] R. Grande, The Distance Between Us. New York: Washington Square Press, 2012. 